
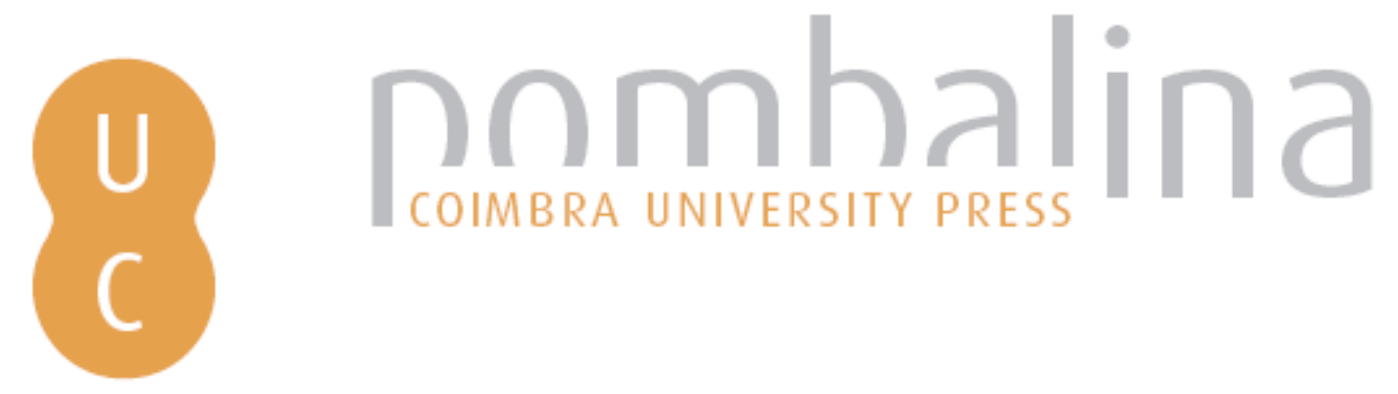

\title{
Evaluating ecological tipping points across levels of wildfire suppression under various climate and fuel treatment scenarios on US northern Rocky Mountain landscapes using landscape simulation
}

\author{
Autor(es): $\quad$ Keane, Robert E.; Gray, Kathy; Davis, Brett; Holsinger, Lisa
}

Publicado por: Imprensa da Universidade de Coimbra

URL persistente:

URI:http://hdl.handle.net/10316.2/44673

DOI:

DOI:https://doi.org/10.14195/978-989-26-16-506_156

Accessed : $\quad$ 26-Apr-2023 09:27:45

A navegação consulta e descarregamento dos títulos inseridos nas Bibliotecas Digitais UC Digitalis, UC Pombalina e UC Impactum, pressupõem a aceitação plena e sem reservas dos Termos e Condições de Uso destas Bibliotecas Digitais, disponíveis em https://digitalis.uc.pt/pt-pt/termos.

Conforme exposto nos referidos Termos e Condições de Uso, o descarregamento de títulos de acesso restrito requer uma licença válida de autorização devendo o utilizador aceder ao(s) documento(s) a partir de um endereço de IP da instituição detentora da supramencionada licença.

Ao utilizador é apenas permitido o descarregamento para uso pessoal, pelo que o emprego do(s) título(s) descarregado(s) para outro fim, designadamente comercial, carece de autorização do respetivo autor ou editor da obra.

Na medida em que todas as obras da UC Digitalis se encontram protegidas pelo Código do Direito de Autor e Direitos Conexos e demais legislação aplicável, toda a cópia, parcial ou total, deste documento, nos casos em que é legalmente admitida, deverá conter ou fazer-se acompanhar por este aviso.

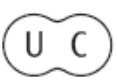




\section{ADVANCES IN}

\section{FOREST FIRE RESEARCH}

\section{8}

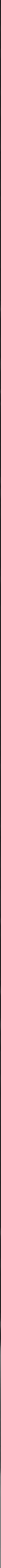


Short contribution - Fire Management

Evaluating ecological tipping points across levels of wildfire suppression under various climate and fuel treatment scenarios on US northern Rocky Mountain landscapes using landscape simulation

\author{
Robert E. Keane ${ }^{1 *}$; Kathy Gray ${ }^{2}$; Brett Davis ${ }^{1}$; Lisa Holsinger ${ }^{1}$ \\ ${ }^{1} *$ US Forest Service, Rocky Mountain Research Station, Missoula Fire Sciences Laboratory, 5775 Hwy 10 \\ West, Missoula, Montana 59808. \{rkeane@fs.fed.us*\} \\ ${ }^{2}$ California State University at Chico, Department of Math and Statistics, 400 West 1st Ave, Chico, CA \\ 95929-0525, \{klgray@csuchico.edu\}
}

Keywords: ecological thresholds; wildland fire use; FireBGCv2; landscape modeling; wildfire; prescribed fire; fuel treatments

\title{
1. Introduction
}

Wildfires are becoming major concerns across the western US because, over the last 20 years, they have increased in frequency, intensity and size in many areas (Westerling 2016). The successful US fire suppression program over the last century has kept fire out of many fire-prone forests resulting in excessive buildups of wildland fuel, specifically surface and crown fuels, which has, in turn, increased the potential wildfires (Keane et al. 2002, Flannigan et al. 2009). This suppression legacy has left US fire management at a crossroads. Fire suppression costs are spiraling out of control, and if fire suppression continues, even more biomass will accumulate to create conditions that will foster even more intense fires than both their contemporary or historical counterparts (Van Wagtendonk 1985). And to make matters worse, future climates in western North America are predicted to be hotter and drier creating longer and more severe fire seasons (Flannigan et al. 2013, Abatzoglou and Williams 2016, Westerling 2016). Increasing fuels and warmer climates will mean firefighters will be asked to fight more dangerous fires, putting themselves at even higher risks for injury and fatality (Withen 2015). The solution to this fire management dilemma may be extremely complex because it must integrate comprehensive pro-active fuel treatment strategies (e.g., prescribed fire, mechanical cuttings) with wildland fire use (WFU: controlled wildfires or letting some fires burn under prescribed conditions) and wildfire suppression initial attack into a more effective fire management strategy (Zimmerman and Bummell 1999). A first step towards developing an integrated strategy may be to identify those critical thresholds of wildfire suppression efforts, primarily in initial attack, where fuels and fire conditions, and associated ecosystem health and resilience, significantly differ from historical conditions when no fires were suppressed, fire hazard was low, and ecosystems were most resilient.

In this study, we use landscape modeling implemented in a complex simulation experiment to create the data for evaluating possible tipping points in wildfire management in the US northern Rocky Mountains (NRM). Wildfire tipping points identified by our statistical techniques were then summarized to develop a set of possible management targets for NRM landscapes. The tipping point levels of fire suppression effort should provide fire managers insight into how many wildfires can be initially attacked before there are major changes in the ecological characteristics of landscapes.

\section{Methods}

The FireBGCv2 landscape ecosystem model was used in a complex simulation experiment to evaluate possible tipping points in wildfire management in the NRM (Keane et al. 2011). We used a fully factorial simulation design where a set of four factors represented different levels of fire 
suppression effort, fuel treatments, climate, and landscape setting. The primary vector of evaluation for this experiment was fire suppression level (FSL) where we simulated ten levels of increasing fire suppression: 0\% suppression (no fires suppressed; historical fire regime) to $90 \%$ suppression (estimated level of current fire suppression) by 10\% levels (e.g., 0, 10, 20, 30.. 90\% suppression). Another factor was Landscape (LAN) with the three levels reflecting the three landscapes: (1) East Fork Bitterroot River (EFBR) on the Bitterroot National Forest, Montana, USA is a 128,000 ha dry mixed-conifer ecosystem with a mixed frequency and severity fire regime; (2) Crown of the Continent $(\mathrm{CROWN})$ is a 100,000 ha mesic mixed-conifer landscape with fire regimes of variable frequencies and severities; and (3) the Yellowstone Central Plateau (YCP) in Yellowstone National Park: a high elevation (>2300 m MSL) landscape with mostly infrequent stand-replacement fire regimes and composed mostly of mature lodgepole pine. We evaluated gradients of fire suppression effort in the context of two other factors. First, we evaluated if tipping points would be different if fuel treatments were employed so we simulated four levels of fuel treatment effort (FTE): (1) no treatments, (2) business as usual (BAU; 3\% landscape treated per year), (3) fully funded fuels program (FF; 10\% landscape treated per year), and (4) no holds bar (NHB; treat everything that needs treatment). All fuel treatments were a combination of cutting and removing all fire-sensitive, shade tolerant species down to $4 \mathrm{~cm} \mathrm{DBH}$ and implementing a low intensity prescribed burn ( $400 \mathrm{~kW} \mathrm{~m}-1$ fireline intensity). We also looked at two climates (CLI) -a historical climate and a future climate (RCP8.5). Each level for each of the four factors was simulated in a multifactorial design with ten replicates for a total of 1,800 simulations for each landscape. In this study, we assumed that landscapes are most resilient when they are within HRV, even in the future. As a result, the base case for each landscape is no fire suppression and no fuel treatments with historical climates that is the estimate of the historical range and variability (HRV) of landscape dynamics. We output values for response variables every 10 years to create a simulation time series of 25 observations for each simulation run. We analysed the time series using ShewhartQCC plots for all seven response variables over the gradient of fire suppression levels, but only show Shewhart QCC plots for a single variable (canopy bulk density; CBD) for both climate scenarios (HIST, RCP8.5), but only two fuels treatment scenarios (None, NHB), for brevity.

\section{Results and Discussion}

We found that approximately 40-70\% of wildfires can be suppressed leaving 30 to $60 \%$ of wildfires to be managed as WFU fires, and we also found that a fuel treatment campaign (BAU, FF, NHB) can allow 10 to $30 \%$ more fires to burn, depending on the intensity of the area treated each year (Figure 1). However, there are caveats to this finding. First, landscape setting greatly influences any potential tipping point in fire suppression level. Landscapes with historically frequent fires, such as EFBR, tend to have higher tipping points in fire suppression $(>60 \%)$ than mixed, less frequent fire regimes, such as the CROWN (>40\%), and stand-replacement, infrequent fire regimes (no tipping point), such as the YCP. This is a result of two interacting factors -fire frequency and simulation time. Landscapes with frequent fires (EFBR) have many fires in the short simulation time, so a reduction in the number of fires may not significantly impact landscape dynamics over the 200 years, but landscapes with long fire return intervals (YCP) have only a few fires during the simulation, and a reduction in these few fires may cause significant changes in landscape dynamics. Another caveat is that the variables used to assess tipping points matter. In our analysis, we used a set of variables that were selected because we thought they may be important to fire management. We found that each variable had its own specific tipping point when using HRV as reference and when we collapsed all seven variables down to two principal component axis (PC1 and PC2), we got an entirely new set of tipping points. A last concern is climate. Tipping points using historical climates are quite different from those in the future, because future climates will be hotter and drier than today. This brings up the question of whether using HRV for the baseline comparison is appropriate if future climates are significant different from historical analogs. In this paper, we assumed that HRV is a good reference because it broadly 
represents those conditions under which most of the biota on the landscapes evolved and as such provides an ecologically viable benchmark. The best way to implement findings from this effort is to simulate both HRV and a set of future ranges of variation which represent new climates and management alternatives and then search for overlaps between HRV and FRVs).

EFBR
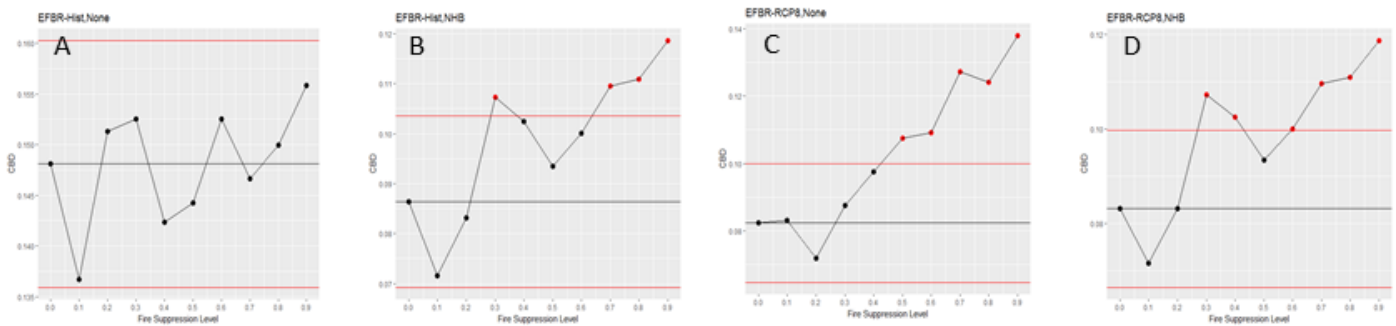

CROWN
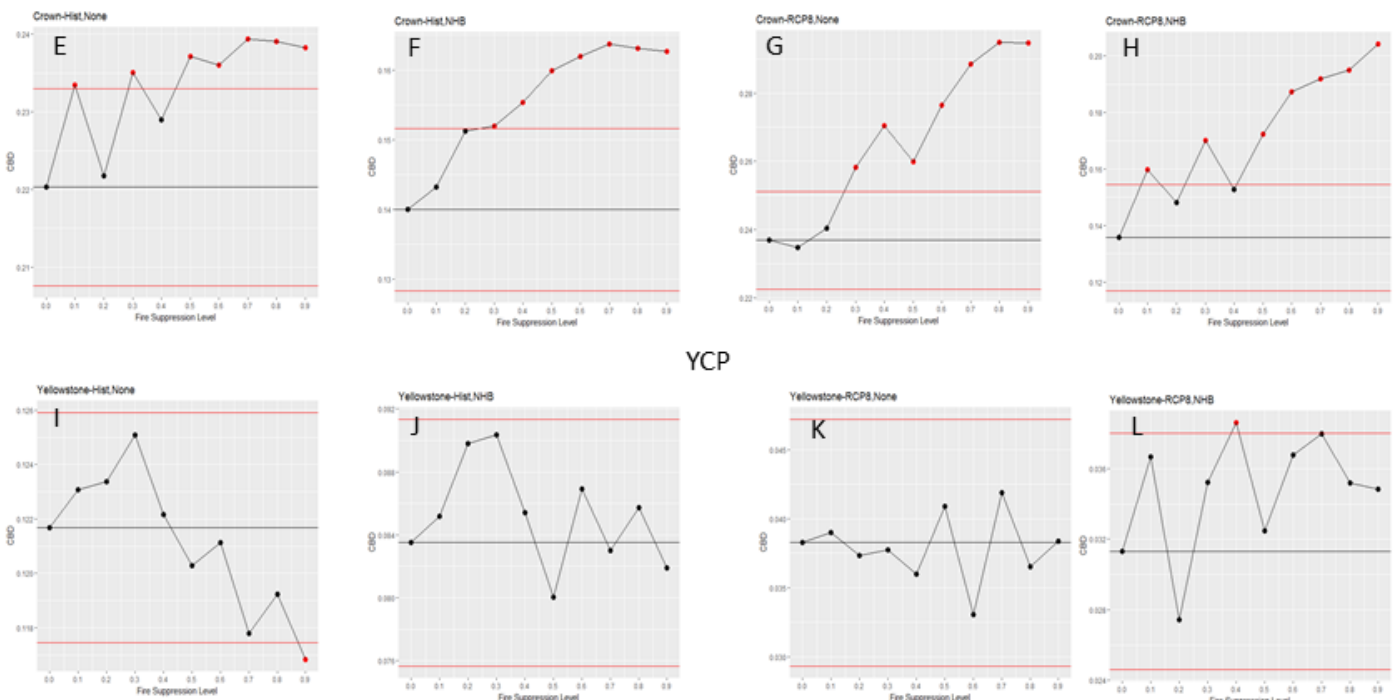

YCP

Figure 1 - Shewhart QCCs for the variable canopy bulk density (kg m-3) for all three study areas (EFBR, CROWN YCP) for both historical (hist) and future (RCP8.5) climate and for only two of the four fuel treatment scenarios (none-no fuel treatments and NHB-no holds barred). Figures arranged by landscape, climate, and fuel treatment with historical weather-no fuel treatment, historical weather-NHB, future weather-no treatments, future weather-NHB for $\operatorname{EFBR}(A, B, C, D), C R O W N(E, F, G, H)$, and $Y C P(I, J, K, L)$

\section{References}

Abatzoglou, J. T. and A. P. Williams. 2016. Impact of anthropogenic climate change on wildfire across western US forests. Proceedings of the National Academy of Sciences 113:11770-11775.

Flannigan, M. D., M. A. Krawchuk, W. J. de Groot, B. M. Wotton, and L. M. Gowman. 2009. Implications of changing climate for global wildland fire. International Journal of Wildland Fire 18:483-507.

Flannigan, M., A. S. Cantin, W. J. de Groot, M. Wotton, A. Newbery, and L. M. Gowman. 2013. Global wildland fire season severity in the 21st century. Forest Ecology and Management 294:5461.

Keane, R. E., Thomas Veblen, Kevin C. Ryan, Jesse Logan, Craig Allen, and B. Hawkes. 2002. The cascading effects of fire exclusion in the Rocky Mountains. Pages 133-153 in J. B. (Editor), editor. Rocky Mountain Futures: An Ecological Perspective. Island Press, Washington DC, USA. 
Keane, R. E., R. A. Loehman, and L. M. Holsinger. 2011. The FireBGCv2 landscape fire and succession model: a research simulation platform for exploring fire and vegetation dynamics. General Technical Report RMRS-GTR-255, U.S. Department of Agriculture, Forest Service, Rocky Mountain Research Station, Fort Collins, CO USA.

Van Wagtendonk, J. W. 1985. Fire suppression effects on fuels and succession in short-fire-interval wilderness ecosystems. Pages 119-126. Proceedings, Symposium and Workshop on Wilderness Fire, Missoula, Montana, November 15-18, 1983 : proceedings of a symposium. Ogden UT : U.S. Dept. of Agriculture Forest Service Intermountain Forest and Range Experiment Station 1985.

Westerling, A. L. 2016. Increasing western US forest wildfire activity: sensitivity to changes in the timing of spring. Philosophical Transactions of the Royal Society of London B: Biological Sciences 371.

Withen, P. 2015. Climate Change and Wildland Firefighter Health and Safety. NEW SOLUTIONS: A Journal of Environmental and Occupational Health Policy 24:577-584.

Zimmerman, T. G. and D. L. Bummell. 1999. Wildland fire management for the 21 st century: evolving applications and capabilities. Pages 316-323 in Proceedings of the Society of American Foresters 1999 national convention. SAF Publication, Portland, Oregn, USA. 